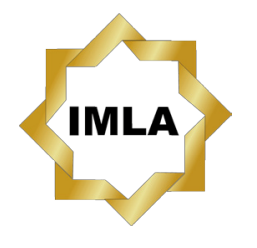

\title{
BAHASA ARAB SEBAGAI BAHASA KEDUA (KAJIAN TEORETIS PEMEROLEHAN BAHASA ARAB PADA SISWA NON-NATIVE)
}

\author{
Ahmad Habibi Syahid \\ Institut Agama Islam Negeri Sultan Maulana Hasanuddin Banten \\ e-mail : habib.syahid@gmail.com
}

Naskah diterima: 18 Maret 2015, direvisi: 12 April 2015, disetujui: 8 Mei 2015.

\begin{abstract}
Discussing the issue of language acquisition is interesting. Acquisition as an unconscious process is important when someone acquire a language. It contrasted with learning, which is a conscious process. The process of language acquisition and language learning influences by some factors. The process of language acquisition can be viewed from the perspectives of psycholinguistic, sociolinguistic, and neurolinguistic. From neurolinguistics perspective examines the nervous system in the human brain has an important role the process of acquiring a foreign language; includes external and internal factors of the human environment. This article discusses the process of Arabic language acquisition for non-native students.
\end{abstract}

Keywords : Arabic language acquisition, language learning, neurolinguistic

\section{Abstrak}

Proses pemerolehan bahasa menjadi salah satu diskursus yang menarik untuk didiskusikan. Terutama proses pemerolehan bahasa asing yang tidak pernah berhenti untuk didiskusikan karena selain terkait dengan konsep pemerolehan bahasa pertama pada anak, juga memiliki keterkaitan, mulai dari proses pembelajaran bahasa sampai dengan pemerolehan bahasa asing. Tentunya terdapat perbedaan antara proses pembelajaran bahasa dengan proses pemerolehan bahasa. Setidaknya proses pemerolehan bahasa dapat dilihat dari dua perspektif yaitu proses pemerolehan bahasa asing dalam bingkai prsikolinguistik dan proses pemerolehan bahasa asing dalam bingkai sosiolinguistik, atau dalam perkembangannya juga dapat dilihat dalam perspektif neurolinguistik yang mengkaji sistem saraf dalam otak manusia terhadap proses pemerolehan bahasa asing.

Kata Kunci : pemerolehan bahasa Arab, pembelajaran bahasa Arab, neurolinguistik

How to Cite:Syahid, Ahmad Habibi. "BAHASA ARAB SEBAGAI BAHASA KEDUA (KAJIAN TEORETIS PEMEROLEHAN BAHASA ARAB PADA SISWA NON-NATIVE)" ARABIYAT : Jurnal Pendidikan Bahasa Arab dan Kebahasaaraban [Online], Volume 2 Number 1 (30 Juni 2015)

Permalink/DOI: http://dx.doi.org/10.15408/a.v2i1.1797 


\section{Pendahuluan}

Kajian tentang pemerolehan bahasa muncul dari pertanyaan-pertanyaan seputar hubungan bahasa dengan menusia, seperti: bagaimana seorang anak masuk dalam dunia bahasa? Bagaimana pengetahuan tentang bahasa muncul pada masa kanak-kanak, dan bagaimana cara berkembangnya? Apa dasar dari proses pemerolehan bahasa? Apa jenis pengetahuan linguistik yang anakanak munculkan pada masa pertumbuhan ${ }^{1}$ Pertanyaan-pertanyaan di atas menjadi semacam milequestions dalam teori pemerolehan bahasa, baik mengenai proses pemerolehan bahasa pertama (mother language) pada anak, maupun proses pemerolehan bahasa asing (second language acquisition/foreign language acquisition) pada siswa non-native di Indonesia terhadap pemerolehan bahasa Arab.

Tarigan menjelaskan mengenai pemerolehan bahasa dalam teori akulturasi bahwa proses pemerolehan bahasa merupakan salah satu aspek akulturasi serta tingkat pengakulturasian seseorang pada kelompok bahasa tertentu dalam memperoleh bahasa lainnya atau yang dimaksud bahasa kedua atau bahasa asing. ${ }^{2}$ Sedangkan akulturasi dalam proses

1 Maria menjelaskan bahwa framework yang digunakan untuk menjawab pertanyaanpertanyaan tersebut, dengan mengadopsi teori yang dipelopori oleh Noam Chomsky yaitu teori generatif transformatif grammar. Lihat Maria Teresa Guasti, Language Acquisition; The Growth of Grammar (London: The MIT Press Cambridge, 2002), h. 1. Menurut Djoko Saryono teori generatif transformatif meyakini bahwa bahasa merupakan cerminan dari pola pikir serta kecendekiawan manusia yang dihasilkan secara baru oleh setiap individu yang dilakukan berdasarkan keinginan dan dalam kesadaran manusia. Seperti dikutip oleh Nana Jumhana, "Pemerolehan Bahasa Pada Anak", Al-Ittijah Jurnal Keilmuan dan Kependidikan Bahasa Arab, Vol 6, No. 2 (Juli - Desember) 2014, h. 109-128.

2 Henry Guntur Tarigan, Pengajaran Pemerolehan Bahasa (Bandung: Angkasa, 2011 Edisi Revisi), h. 205-206. pemerolehan bahasa ditentukan oleh tingkat atau jarak sosial ${ }^{3}$ seseorang serta psikisnya $^{4}$ terhadap kebudayaan bahasa sasaran tersebut. Salah satu contoh bahwa orang Indonesia memperoleh bahasa Arab ditentukan oleh hubungan antara faktor sosial atau psikis dengan kebudayaan bahasa Arab tersebut.

Kajian tentang pemerolehan bahasa asing pada siswa non-native di Indonesia menjadi sangat penting untuk mengetahui bagaimana orang Indonesia memperoleh bahasa asing dan mampu memahami kaidah-kaidah pada bahasa sasaran tersebut. Kemudian bagaimana mereka mampu mempersepsi ujaran-ujaran dalam bahasa asing dan mampu memahaminya sehingga memiliki keterampilan dalam berbahasa tutur dengan menggunakan bahasa asing. Melalui kajian ini dapat diketahui pula bagaimana manusia yang sudah memiliki bahasa pertama dan kedua dapat memproduksi ujaran dalam bahasa lainnya (foreign language) apabila dia mengetahui kaidah-kaidah dalam bahasa asing tersebut yang harus diikuti yang dia peroleh dalam proses pembelajaran.

Tulisan ini membahas garis besar permalasahan-permasalahan dalam proses pemerolehan bahasa asing pada siswa nonnative di Indonesia terutama dalam proses

3 Jarak sosial merupakan akibat dari sejumlah faktor yang mempengaruhi seseorang sebagai anggota kelompok sosial dalam kontaknya dengan kelompokbahasasasaran. LihatAhmad HabibiSyahid, "Kepribadian Ekstrovert-Introvert dan Pemerolehan Bahasa Kedua Perspektif Psikolinguistik pada Santri Pondok Modern", Al-Qalam Jurnal Kajian Keislaman, Vol. 31, No. 2 (Juli-Desember) 2014, h. 399-426.

4 Jarak psikis merupakan akibat dari berbagai faktor efektif yang berkaitan dengan seseorang sebagai satu pribadi dan individu. Lihat Ahmad Habibi Syahid, "Kepribadian EkstrovertIntrovert dan Pemerolehan Bahasa Kedua Perspektif Psikolinguistik pada Santri Pondok Modern", AlQalam Jurnal Kajian Keislaman, Vol. 31, No. 2 (JuliDesember) 2014, h. 399-426. 
pemerolehan bahasa Arab sebagai fondasi dalam mempelajari kaidah-kaidah serta aturan-aturan dalam bahasa arab sehingga mampu memahami dan memproduksi ujaran-ujaran dalam bahasa Arab. Dengan demikian, yang menjadi pokok permasalahan dalam tulisan ini adalah: 1) Apa konsep dasar pemerolehan bahasa dan pemerolehan bahasa kedua vs bahasa asing. 2) Bagaimana teori pemerolehan bahasa kedua/asing. 3) Bagaimana model pemerolehan bahasa asing yang sesuai dengan pembelajaran bahasa asing di Indonesia. Sedangkan tujuan penelitian ini adalah untuk : mengetahui pengertian pemerolehan bahasa, teori pemerolehan bahasa kedua/asing, dan model pemerolehan bahasa asing yang sesuai dengan pembelajaran bahasa asing di Indonesia.

\section{Pembahasan}

\section{Pengertian Pemerolehan Bahasa}

Istilah pemerolehan dipakai untuk padanan kata dalam bahasa Inggris yaitu acquisition, yakni proses pemerolehan bahasa ${ }^{5}$ yang dilakukan oleh anak secara

5 Pemerolehan bahasa pada anak mungkin berbeda dengan proses penguasaan bahasa pada fase pembelajaran. Penguasaan bahasa pada anak lebih bersifat natural (native language) sedangkan penguasaan bahasa pada fase pembelajaran dipengaruhi oleh proses belajar bahasa. Tentunya berbeda pula antara proses pemerolehan bahasa asing dengan proses pembelajaran bahasa asing. Krashen menjelaskan bahwa orang dewasa memiliki dua cara yang berbeda dalam mengembangkan kompetensi bahasa kedua (bahasa asing). Dia menjelaskan bahwa proses pemerolehan bahasa asing pada orang dewasa, sama dengan cara anak-anak mengembangkan kemampuan bahasa pertama mereka. Sedangkan cara kedua, untuk mengembangkan kompetensi dalam berbahasa atau terhadap pemerolehan bahasa asing dapat dilakukan dengan cara mempelajari bahasa tersebut. Hipotesis dalam pemikirannya bahwa kemampuan memperoleh bahasa selain bahasa ibu tidaklah hilang walaupun secara fisik ada perkembangan. Stephen D Krashen, Second Language Acquisition and Second Language Learning (Pergamon Press Inc, 1981), h. 2. natural terhadap bahasa ibunya. ${ }^{6}$ Studi tentang pemerolehan bahasa kedua (asing) atau disebut second language acquisition (SLA)/ foreign language acquisition (FLA) dapat dipahami sebagai bidang ilmu intradisipliner yang berusaha untuk mengungkap tentang faktor-faktor di luar bahasa terhadap proses pemerolehan bahasa kedua (asing) seperti faktor psikis dan faktor sosial. Faktor-faktor tersebut merupakan disiplin ilmu psikolinguistik, sosiolinguistik, ataupun neurolinguistik yang mempengaruhi proses pemerolehan bahasa kedua (asing). ${ }^{7}$

Pemerolehan bahasa biasanya dibedakan dari pembelajaran bahasa (language learning). Pembelajaran bahasa berkaitan dengan proses-proses yang terjadi pada waktu seorang anak mempelajari bahasa kedua (asing), tentunya setelah dia memperoleh kemampuan bahasa pertamanya. ${ }^{8}$

Fromkin dan Rodman menjelaskan bahwa ada dua pengertian mengenai pemerolehan bahasa. Pertama, pemerolehan bahasa mempunyai permulaan yang mendadak, tiba-tiba. Kedua, pemerolehan bahasa memiliki suatu permulaan yang gradual yang muncul dari prestasi-prestasi motorik,

6 Abdul Chaer dalam Nana Jumhana, "Pemerolehan Bahasa Pada Anak", Al-Ittijah Jurnal Keilmuan dan Kependidikan Bahasa Arab, Vol 6, No. 2 (Juli - Desember) 2014, h. 109-128.

$7 \quad$ Numa Markee, Conversation Analysis Second Language Acquisition Research (Lawrence Erlbaum Associates, Inc, 2000), h. 5.

8 Nana Jumhana, "Pemerolehan Bahasa Pada Anak", Al-Ittijah Jurnal Keilmuan dan Kependidikan Bahasa Arab, Vol 6, No. 2 (Juli - Desember) 2014, h. 109-128. Nana menambahkan bahwa pemerolehan bahasa berkaitan dengan bahasa pertama, sedangkan pembelajaran bahasa berkaitan dengan bahasa kedua (asing). 
soial, dan kognitif pralinguistik. ${ }^{9}$ Senada dengan pengertian Fromkin dan Rodman, Yukio ${ }^{10}$ juga menjelaskan bahwa pada proses pemerolehan bahasa kedua, seorang pembelajar memperoleh bahasa pada saat dia berusaha untuk mempelajari bahasa tersebut.

Beberapa penjelasan mengenai pengertian permerolehan bahasa tersebut, cenderung terjadi pada proses pemerolehan bahasa ibu atau bahasa pertama. Namun, pada perkembangannya manusia mengalami fase belajar. Pada fase ini, manusia dihadapkan pada penguasaan bahasa kedua/bahasa asing. Tentunya penguasaan tersebut lebih cenderung melalui proses pembelajaran, akan tetapi dalam studi tentang pembelajar bahasa, terjadi proses pemerolehan bahasa kedua/bahasa asing pada saat dia mempelajarinya. Karena itu, muncullah istilah pemerolehan bahasa kedua atau pemerolehan bahasa asing yang berakar pada teori pemerolehan bahasa pertama dan dibedakan antara proses pembelajaran bahasa dengan proses pemerolehan. Walaupun pada proses pemerolehan bahasa kedua/ bahasa asing dimulai dari proses pembelajaran.

\section{Pemerolehan Bahasa Kedua vs Bahasa Asing}

Dalam memaknai istilah acquisition atau language acquisition, terutama

9 Nana Jumhana, "Pemerolehan Bahasa Pada Anak", Al-Ittijah Jurnal Keilmuan dan Kependidikan Bahasa Arab, Vol 6, No. 2 (Juli - Desember) 2014, h. 109-128.

10 Yukio Tono, "The Role of Learner Corpora in SLA Research and Foreign Language Teaching: The Multiple Comparison Approach", a Dissertation at Lancaster University Department of Applied Linguistics and Modern English Language, February), 2002. h. 26. istilah tentang second language acquisition atau dikenal dengan istilah pemerolehan bahasa kedua, sangat sulit untuk menemukan pemaknaan yang tepat terutama terhadap pemerolehan bahasa kedua di Indonesia. Belum ada jawaban yang sederhana terkait pertanyaan tentang 'what is second language acquisition?' atau apa itu SLA (pemerolehan bahasa kedua)?.11

Studi tentang pemerolehan bahasa kedua sangatlah komplek, karena hal tersebut dihadapkan pada fenomenafenomena yang muncul kecuali pada poin-poin tertentu manakala hal tersebut dipandang dalam terminologi yang berbeda-beda. Hal ini senada ketika seseorang yang berbeda memaknai sesuatu hal. Pasti cara pandang dan makna yang keluar akan berbeda. Yukio mengatakan bahwa dalam studinya tentang pembelajar bahasa, perbedaan antara bahasa kedua, ketiga (atau lebih dari 4) sangat sulit. Hal ini disebabkan karena pada bahasa tertentu memiliki paham multilingualisme, dan istilah 'second' secara umum digunakan untuk merujuk pada bahasa lainnya selain bahasa ibu. ${ }^{12}$

11 Yukio Tono, "The Role of Learner Corpora in SLA Research and Foreign Language Teaching: The Multiple Comparison Approach", h. 21. Dalam disertasinya Yukio mengklasifikasikan terkait studi tentang pembelajar bahasa. Dia menyinggung masalah-masalah yang terkait dengan istilah pemerolehan bahasa kedua, di antaranya adalah pemerolehan bahasa kedua vs bahasa ketiga (second vs third language acquisition), pemerolehan bahasa kedua vs bahasa asing (second vs foreign language acquisition), naturalistik vs pembiasaan pemerolehan bahasa kedua (naturalistic vs instructed second language acquisition), kompetensi vs performansi (competence vs performance) dan yang terakhir adalah pemakaian dan penggunaan (usage vs use).

12 Yukio Tono, "The Role of Learner Corpora in SLA Research and Foreign Language Teaching: The Multiple Comparison Approach", h. 22. 
Pengertian proses pemerolehan bahasa kedua dengan proses pemerolehan bahasa asing dalam konteks pembelajar bahasa (language learners) di Indonesia memiliki perbedaan, istilah tersebut bisa dijelaskan dalam pertanyaan sederhana, seperti: apa yang dimaksud dengan pemerolehan bahasa kedua? dan apa yang dimaksud dengan pemerolehan bahasa asing? Apakah berbeda?

Merujuk pada pendapat Yukio ${ }^{13}$ tentang pemerolehan bahasa kedua atau pemerolehan bahasa asing, dia berpendapat bahwa kedua istilah tersebut digunakan sesuai dengan keadaan yang dibuat atau dilakukan. Dia mencontohkan, bahasa Inggris tidak digunakan sebagai bahasa utama dalam komunikasi di masyarakat Jepang. Bahasa Inggris merupakan satu materi inti yang hanya dipelajari di dalam kelas. Maka dalam kasus tersebut bahasa Inggris lebih cenderung dikatakan sebagai bahasa asing. Sedangkan dalam kasus tertentu, bahasa Inggris digunakan dalam dunia institusi (akademisi), dan juga digunakan sebagai alat komunikasi dalam dunia komunikasi sosial, maka bahasa Inggris dapat dikatakan sebagai bahasa kedua, setelah bahasa ibu pembelajar yang bukan bahasa Inggris.

Dalam konteks pembelajar bahasa di Indonesia, istilah pemerolehan bahasa kedua atau pemerolehan bahasa asing dapat digunakan keduanya. Hal ini dapat dikatakan jika merujuk pada model sekolah di Indonesia. Dua dari model sekolah yang berbeda di Indonesia,

13 Yukio Tono, "The Role of Learner Corpora in SLA Research and Foreign Language Teaching: The Multiple Comparison Approach", h. 22-23. yang menjadi perbandingan mengenai pembelajaran dan pemerolehan bahasa adalah model sekolah berasrama dengan model sekolah non-asrama. Model sekolah berasrama atau cenderung dengan Islamic Boarding School (Pondok Pesantren Modern) menekankan para siswa mempelajari dua bahasa asing yaitu bahasa Arab dan Inggris. Selain siswa mempelajari bahasa sing tersebut, siswa juga diarahkan kepada penggunaan kedua bahasa asing tersebut dalam komunikasi sehari-hari. Jika merujuk pada pengertian Yukio maka kasus ini dapat dikatakan proses pembelajaran serta pemerolehan bahasa kedua, karena bahasa Arab atau pun bahasa Inggris tidak lagi hanya dipelajari di dalam kelas, tetapi juga digunakan dalam percakapan dan komunikasi sehari-hari.

Berbeda dengan model sekolah nonasrama, seperti sekolah-sekolah umum biasa. Salah satu contoh pembelajaran bahasa Arab di Madrasah Tsanawiyah atau Madrasah Aliyah. Bahasa Arab hanya menjadi satu materi pelajaran yang diajarkan di dalam kelas. Bahasa Arab cenderung belum digunakan dalam komunikasi sehari-hari di sekolah. Sehingga tidak dapat dikatakan bahasa Arab sebagai bahasa kedua melainkan bahasa Asing.

Pada fase pemerolehan bahasa kedua, tentunya didasari pada teoriteori pemerolehan bahasa pertema. Proses pemerolehan bahasa pertama pada anak erat sekali kaitannya dengan perkembangan sosial anak dan karenanya juga erat hubungannya dengan pembentukan identitas sosial. Mempelajari bahasa pertama merupakan salah satu perkembangan 
menyeluruh anak menjadi anggota penuh suatu masyarakat. ${ }^{14}$

\section{Teori-teori Pemerolehan Bahasa Kedua}

Dalam perkembangan ilmu linguistik, studi tentang pemerolehan bahasa pun ikut berkembangan. Pada awalnya teori pemeorlehan bahasa cenderung pada pemerolehan bahasa pertama pada anak. Dua di antaranya merupakan teori besar yang hingga saat ini masih menjadi perdebatan, yaitu teori Behavioristik ${ }^{15}$ dan teori Mentalistik ${ }^{16}$.

Dalam aliran Behavioristik ada tokoh yang membedakan dua macam perilaku sehubungan dengan proses belajar, yaitu B.F. Skinner. Skinner, salah satu tokoh aliran Behavioristik dengan teori besarnya Pembiasaan Operan (Operant Conditioning). Sedangkan dalam aliran Mentalistik dikenal tokoh dengan teori besarnya

\footnotetext{
14 Nana Jumhana, "Pemerolehan Bahasa Pada Anak", Al-Ittijah Jurnal Keilmuan dan Kependidikan Bahasa Arab, Vol 6, No. 2 (Juli - Desember) 2014, h. 109-128. Nana menjelaskan bahwa bahasa dapat memudahkan anak mengekspresikan gagasan, kamauannya dengan cara yang benar-benar dapat diterima secara sosial. Begitu pula dalam pemerolehan bahasa kedua. Pembelajaran bahasa kedua dapat didasari pada tujuan untuk berkembang secara menyeluruh untuk menjadi anggota dalam satu komunitas masyarakat tertentu, serta mampu menyampaikan gagasan, serta ide tanpa harus menghadapi persoalan keterampilan berbahasa.

15 Teori Behavioristik cenderung mengambil perilaku yang dapat diamati sebagai titik tolak untuk deskripsi dan penjelasannya. Nana Jumhana, "Pemerolehan Bahasa Pada Anak", Al-Ittijah Jurnal Keilmuan dan Kependidikan Bahasa Arab, Vol 6, No. 2 (Juli - Desember) 2014, h. 109-128.

16 Teori Mentalistik mengambil struktur dan cara kesadaran sebagai dasarnya, seperti kesadaran, rencana, maksud, dan konsep. Nana Jumhana, "Pemerolehan Bahasa pada Anak", Al-Ittijah Jurnal Keilmuan dan Kependidikan Bahasa Arab, Vol 6, No. 2 (Juli - Desember) 2014, h. 109-128.
}

Universal Grammar atau kompetensi linguistik yaitu Avram Noam Chomsky.

Kedua teori besar dalam studi pemerolehan bahasa dapat digunakan untuk melihat proses pemerolehan bahasa terutama pada pemerolehan bahasa kedua. Di bawah ini beberapa penjelasan teori-teori Behavioristik dan Mentalistik digunakan dalam studi pemerolehan bahasa kedua.

\section{a. Teori Pembiasaan Operan (Aliran Behaviorisme)}

Pembiasaan operan yang dikembangkan oleh seorang ilmuan bernama B.F. Skinner sekira pertengahan abad ke- $20^{17}$ menitikberatkan pada teori pemerolehan bahasa dengan model S-R (stimulusrespon). Model S-R dalam teori pembiasaan operan ini menelisik pada hubungan antara stimulan yang berasal dari luar organisme dengan respon daridalamorganisme tersebut atau reaksi yang muncul atas masuknya stimulan dari luar organisme. ${ }^{18}$ Salah satu contoh dalam proses pembelajaran bahasa asing, manusia menjadi satu organisme yang mempelajari bahasa. Dia akan menerima stimulan-stimulan dari luar diri manusia seperti, lingkungan, buku-buku, dan lainnya yang akan direspon oleh manusia sebagai organisme itu sendiri dengan memunculkan reaksi-reaksi atas stimulan seperti reaksi dengan menggunakan bahasa sasaran dalam percakapan sehari-hari.

17 Henry Guntur Tarigan, Psikolinguistik (Bandung: Angkasa, 2009), Edisi Revisi, h. 114.

18 Nana Jumhana, "Pemerolehan Bahasa Pada Anak", Al-Ittijah Jurnal Keilmuan dan Kependidikan Bahasa Arab, Vol 6, No. 2 (Juli - Desember) 2014, h. 109-128. 
Skinner juga menjelaskan bahwa stimulan seperti hadiah, imbalan merupakan konsep dari model pemerolehan bahasa S-R yang dapat mempengaruhi frekuensi dan intensitas suatu reaksi menjadi lebih besar dalam teorinya disebut dengan law of effect (hukum pengaruh). ${ }^{19}$

Dalam pengembangan teorinya, Skinner melakukan sebuah eksperimen terhadap seekor tikus untuk mendeskripsikan model S-R (stimulus, respon). Senada dengan gurunya, Pavlov yang menggunakan seekor anjing dalam memahami konsep pemerolehan bahasa. Dalam pengamatannya terhadap seekor tikus, dia melakukan eksperimen dengan meletakkan tikus tersebut ke dalam jeruji besi. Kemudian di dalam kandang tersebut dia melatakkan dua buah tongkat pengungkit dan di atas punggung kandang diletakkan dua buah mangkuk. Mangkuk pertama dia isi dengan makanan dan mangkuk kedua dia isi dengan bedak gatal. Jika tikus itu menginjak tongkat pengungkit yang pertama, maka tikus tersebut akan mendapatkan makanan, namun jika tikus itu menginjak tongkat pengungkit kedua maka tikus tersebut akan terkena bedak gatal. Dari percobaan itu, tikus mampu belajar dari pengalaman setelah ia mencoba menginjak kedua tongkat di dalam kandang dan setelah itu tikus tersebut selalu menginjak tongkat pertama dan akan mendapatkan makanan. Tikus tersebut tidak lagi

19 Henry Guntur Tarigan, Psikolinguistik, h. 115. menginjak tongkat kedua yang berisi bedak gatal. ${ }^{20}$

Stimulus dalam teori pembiasaan operan mengacu pada semua hal tentang perubahan yang ada pada lingkungan. Aly Muhammad Khauly mengatakan bahwa stimulus dapat bersumber dari luar organisme atau juga dari dalam organisme. Dari luar organisme seperti suara keras, ujaran, cahaya dan lainnya. Sedangkan stimulus yang berasal dari dalam organisme atau manusia itu seperti rasa lapar, keinginan untuk makan, atau bahkan keinginan untuk berbicara. ${ }^{21}$

Dalam teori pembiasaan operan, Skinner membagi ke dalam dua perilaku dalam pemerolehan bahasa. Pertama adalah perilaku jawaban (respondent behavior). Pada fase perilaku ini, reaksi timbul dengan sendirinya, segera setelah stimulus muncul. Kedua adalah perilaku operan (operant behavior). Pada fase ini stimulusnya tidak dibangkitkan, akan tetapi timbul dari organisme itu sendiri. Dalam hal ini Skinner mendasarkan teorinya pada prinsip bahwa jika suatu perbuatan mengakibatkan efek tertentu, kemungkinan bahwa jika perbuatan itu diulang akan memberi efek yang lebih atau justru jika ditinggalkan yang akan meningkat. Istilah ini bisa disebut pengulangan positif jika perbuatannya diulangi lebih sering, akan tetapi jika perbuatannya tidak

20 Ghina Fathonah, "Akuisisi Bahasa Kedua", Tesis di Sekolah Pascasarjana UIN Syarif Hidayatullah Jakarta, 2009, h. 32-33. 35. 
diulangi maka disebut penguatan negatif. ${ }^{22}$

Teori Behaviorisme model pembiasaan operan yang dipelopori oleh Skinner ini memiliki pengaruh yang sangat luas dan mendalam dalam diskursus pemerolehan bahasa, baik dalam pemerolehan bahasa pertama, atau pun pemerolehan bahasa kedua. Model ini menjadi representasi dalam bidang pemerolehan dan pembelajaran bahasa. ${ }^{23}$

\section{b. Kompetensi Linguistik (Aliran Mentalistik)}

Pemerolehan bahasa tidak terlepas dari piranti pemerolehan atau acquisition device, yang merupakan piranti dari hipotesis pemerolehan bahasa yang berdasarkan pada input data linguistik primer dari sebuah bahasa, yang menghasilkan satu output yang terdiri atas satu tata bahasa secara deskriptif. Gambaran tentang pemerolehan bahasa bisa dilihat pada gambar berikut ini. ${ }^{24}$

\footnotetext{
22 Nana Jumhana, "Pemerolehan Bahasa Pada Anak", Al-Ittijah Jurnal Keilmuan dan Kependidikan Bahasa Arab, Vol 6, No. 2 (Juli - Desember) 2014, 109-128.

23 Dalam teori Behavioristik yang dititikberatkan adalah pada proses penulusuran secara empiris. Kajiannya lebih melihat pada perilaku nyata dibandingkan pada perilaku yang bersifat mentalistik. Secara sederhana aliran teori ini mengutamakan suatu perlikau yang dapat diamati dengan indra manusia, dapat diukur dan dilukiskan secara pasti, dan lebih melihat pada faktor-faktor eksternal diri manusia. Nana Jumhana, "Pemerolehan Bahasa Pada Anak", Al-Ittijah Jurnal Keilmuan dan Kependidikan Bahasa Arab, Vol 6, No. 2 (Juli - Desember) 2014, h. 109-128.

24 Henry Guntur Tarigan, Psikolinguistik, h. 227.
}

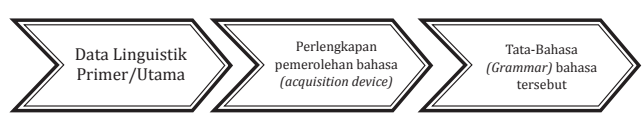

Gambar di atas mendeskripsikan tentang pemerolehan bahasa menurut aliran mentalistik atau disebut dengan kompetensi linguistik. Teori ini dikembangkan oleh seorang ilmuwan yang tidak sependapat dengan teori Behaviorisme. Dia menganggap bahwa Skinner dengan teorinya keliru dalam memahami kodrat bahasa. Menurutnya bahasa bukan merupakan bagian dari hasil pembentukan dari pengulangan atau pembiasaan, akan tetapi bahasa terdiri dari satu sistem yang diatur oleh seperangkat peraturan (rule-governder). Bahasa diidentikkan suatu yang kreatif dan memiliki ketergantungan struktur. Dia menyangkal pendapat Skinner bahwa kedua kodrat tersebut seperti suatu yang kreatif dan bergantung pada struktur hanya dimiliki oleh manusia. Tidak bisa disamakan dengan pengondisian terhadap hewan atau pembiasaan yang dilakukan oleh Skinner dan gurunya Pavlov. ${ }^{25}$

Avram Noam Chomsky menjadi pelopor dalam perkembangan teori mentalistik atau aliran nativis, karena teori yang dikembangkannya yaitu Linguistik Generatif Transformatif. Maria $^{26}$ menjelaskan para Nativis memandang bahwa pemerolehan

\footnotetext{
25 Soenjono, Psikolinguistik Pengantar Pemahaman Bahasa Manusia, (Jakarta: Yayasan Obor Indonesia, 2008), Edisi Ketiga, h. 236.

26 Maria T Guasti, Language Acquisition The Growth of Grammar (London: A Bradford Book The MIT Press Cambridge, 2002), h. 18.
} 
bahasa kedua berawal dari interaksi antara faktor bawaan dengan faktor lingkungan.

Chomsky menuturkan bahwa anak memperoleh bahasa itu bukan seperti piring kosong, tabularasa, dia memperoleh bahasa sama seperti mereka memperoleh kemampuan untuk berdiri dan berjalan. Manusia telah dibekali dengan sebuah alat, disebut LAD (language acquisition device) atau piranti pemerolehan bahasa. Selain dia mengatakan bahwa manusia memiliki LAD dalam memperoleh bahasa, hanya manusia juga yang memiliki bahasa. Menurutnya, bahasa merupakan sesuatu yang hanya dimiliki manusia seperti ujaran-ujaran dan tidak dimiliki oleh hewan sebab bahasa merupakan sistem yang memiliki peraturan tertentu. ${ }^{27}$

Chomsky dianggap sebagai pencetus dari gagasan kompetensi linguistik. Dia mengaitkan pengetahuan pembicara yang ideal dengan struktur gramatikal bahasanya. Dia menulis: "teori linguistik berkaitan dengan pembicara-pendengar yang ideal, dalam ujuran homogenitas, siapa yang tahu apakah bahasa yang digunakan sudah sempurna atau salah oleh kondisi tata bahasa yang tidak relevan seperti sebagai keterbatasan memori, gangguan, pergeseran perhatian dan minat, dan kesalahan (acak atau karakteristik) dalammenerapkan pengetahuannya tentang bahasa dalam kinerja

27 Soenjono, Psikolinguistik Pemahaman Bahasa Manusia, h. 236. aktual". ${ }^{28}$ Namun bagian yang sukar sebenarnya dalam teori Chomsky adalah menemukan secara tepat apa sebenarnya bakat atau bawaan (innate) itu. ${ }^{29}$

\section{Model Pemerolehan Bahasa Kedua Stimulan dan Respon pada Siswa Non-Native di Indonesia}

Model pemerolehan bahasa kedua dengan konsep stimulan dan respon merujuk pada teori aliran behaviorisme yaitu bahwa kompetensi bahasa didasarkan pada tabularasa atau konsep piring kosong. Model ini menitikberatkan padakonsep nyatayang bisa dibuktikan secara empiris. Salah satu contoh pemerolehan kemampuan berbahasa tutur tidak bisa disandarkan pada teori bahwa manusia memiliki piranti pemerolehan bahasa. Manusia diibaratkan seperti piring kosong yang diberikan stimulan. Kemudian stimulan diberikan penguatan dengan cara pengulangan.

Dalam model stimulan dan respon pemerolehan bahasa Arab pada siswa non-native di Indonesia dapat diaplikasikan terhadap model pemerolehan bahasa Arab dengan stimulan pembelajaran keterampilan berbicara. Dalam pembelajaran keterampilan berbicara terutama pada peningkatan kemampuan berbicara diperlukan latihan yang dilakukan secara berulang-ulang. Pengulangan ini yang disebut dalam model S-R dengan perilaku jawaban dan perilaku operan

28 Marysia Johnson, A Philosophy of Second Language Acquisition, (London: Yale University Press, 2004), h. 86.

29 Vanda Herdinata, Dasar-Dasar Psikolinguistik, h. 35. E-Book. Accesed: http://vanda. lecture.ub.ac.id/ pada tanggal 9 September 2013. 
mendapatkan stimulan dan muncul reaksi atau respon dari timbulnya stimulan tersebut. ${ }^{30}$

Keterampilan berbicara bukanlah merupakan keterampilan yang sederhana yang dapat dikuasai dalam jangka waktu yang singkat. Dengan kata lain, menurut Brown, keterampilan berbicara merupakan keterampilan yang komplek yang berkaitan dengan keterampilan mikro antara lain adalah sebagai berikut: (1) keterampilan menghasilkan ujaran-ujaran yang bervariasi; (2) menghasilkan fonemfonem dan varian-varian alophon lisan yang berbeda dalam bahasa; (3) menghasilkan pola tekanan, katakata yang mendapat dan yang tidak mendapat tekanan, struktur ritmis dan intonasi; (4) menghasilkan bentukbentuk kata dan frase yang diperpendek; (5) menggunakan sejumlah kata yang tepat untuk mencapai tujuantujuan pragmatis; (6) menghasilkan pembicaraan yang fasih dalam berbagai kecepatan yang berbeda; (7) mengamati bahasa lisan yang dihasilkan dan menggunakan berbagai strategi yang bervariasi, meliputi pemberhentian sementara, pengoreksian sendiri, pengulangan untuk kejelasan pesan; (8) menggunakan kelas kata (kata benda, kata kerja, dan lain-lain), sistem (tenses, agreement, dan jamak/ plural, pengurutan kata, pola-pola aturan-aturan dan bentuk ellipsis; (9) menghasilkan pembicaraan yang menggunakan elemen-elemen alami dalam frase, stop, nafas, dan kalimat yang tepat; (10) mengekspresikan

30 Nana Jumhana, "Pemerolehan Bahasa Pada Anak", Al-Ittijah Jurnal Keilmuan dan Kependidikan Bahasa Arab, Vol 6, No. 2 (Juli - Desember) 2014, h. 109-128. makna tertentu dalam bentukbentuk gramatika yang berbeda; (11) menggunakan bentuk-bentuk kohesif dalam diskursus lisan; (12) menyelesaikanfungsi-fungsikomunikasi dengan tepatmenurutsituasi, partisipan dan tujuan; (13) menggunakan register, implikatur, aturan-aturan pragmatik dan fitur-fitur sosiolinguistik yang tepat dalam komunikasi langsung; (14) menunjukkan hubungan antara kejadian dan mengkomunikasikan hubungan-hubungan antara ide utama, ide pendukung, informasi lama, informasi baru, generalisasi, dan contoh; (15) menggunakan bahasa wajah, kinetik, bahasa tubuh dan bahasa-bahasa nonverbal lainnya yang bersamaan dengan bahasa verbal untuk menyampaikan makna dan; (16) mengembangkan dan menggunakan berbagai strategi berbicara memberikan tekanan pada kata kunci parafrase, menyediakan pertolongan dan secara cepat menilai seberapa baik interlocutor memahami apa yang akan dikatakan. ${ }^{31}$

Asumsi bahwa keterampilan berbicara tidak dapat dikuasai dalam waktu yang singkat, bahwa dibutuhkan stimulan serta pengulanganpengulangan untuk mampu menguasai keterampilan berbicara tersebut. Stimulan yang diberikan dapat berupa ujaran-ujaran yang sesuai dengan tata bahasa dalam bahasa sasaran serta latihan-latihan yang dilakukan sebagai bentuk dari reaksi stimulan yang muncul.

Selain membutuhkan pengulanganpengulangan, model pemerolehan

31 Yuan Martina Dinata, "Pendekatan Berbasis Tugas, Kepribadian Ekstrovert dan Keterampilan Berbicara Bahasa Arab", Tesis di SPS UIN Syarif Hidayatullah Jakarta, 2009. h. 22-23. 
bahasa S-R senada dengan pandapat Robert Lado. Dia menyebutkan beberapa prinsip-prinsip pengajaran bahasa, di antaranya prinsip berbicara sebelum menulis, belajar melalui praktik. Melihat dari fungsi bahasa sebagai alat untuk berkomunikasi maka tujuan pembelajaran utama pun adalah agar siswa memiliki kompetensi berbahasa yang digunakan untuk berkomunikasi antar sesama. ${ }^{32}$ Berbicara merupakan satu stimulan yang muncul dari keinginan untuk berbicara, sehingga reaksi yang muncul pada saat berbicara adalah keinginan untuk menuliskan sesuatu disebut sebagai respon. Begitu pula belajar merupakan satu stimulan yang dapat dikuatkan dengan pengulangan terus menerus sehingga respon yang muncul untuk melakukan penguatan atau pengulangan dengan melakukan satu praktik sebagai proses penguatan serta pengulangan dari stimulan yang timbul.

Model pemerolehan bahasa kedua stimulan dan respon menjadi teori atau model yang dapat digunakan bagi siswa non-native di Indonesia dalam pemerolehan bahasa Arab terutama pada pemerolehan berbahasa tutur atau keterampilan berbicara.

\section{Simpulan}

Dari uraian yang dipaparkan di atas dapat ditarik kesimpulan sebagai berikut:

1. Proses pemerolehan bahasa terjadi di dalam otak seseorang ketika dia memperoleh bahasa pertamanya. Sedangkan pada pemerolehan bahasa kedua bisa terjadi seperti pada

32 Yuan Martina Dinata, "Pendekatan Berbasis Tugas, Kepribadian Ekstrovert dan Keterampilan Berbicara Bahasa Arab", h. 23. pemerolehan bahasa pertama, akan tetapi juga bisa terjadi melalui proses belajar.

2. Pemerolehan bahasa kedua diasumsikan pada pemerolehan bahasa yang didapat setelah pemerolehan bahasa pertama, dan Bahasa kedua tidak hanya menjadi diskursus di dalam lingkungan kelas melainkan juga digunakan dalam komunikasi sehari-hari di satu masyarakat tertentu. Sedangkan pemerolehan bahasa asing diasumsikan bahwa bahasa asing hanya dipelajari di dalam kelas.

3. Model pemerolehan bahasa kedua dengan model Stimulan-Respon merujuk pada teori bahwa segala sesuatu terutama pada keterampilan berbahasa dibutuhkan penguatan, pengulangan serta latihan-latihan sebagai proses pemerolehan bahasa kedua tersebut. []

\section{Daftar Rujukan}

Dinata, Yuan Martina. "Pendekatan Berbasis Tugas, Kepribadian Ekstrovert dan Keterampilan Berbicara Bahasa Arab", Tesis di SPS UIN Syarif Hidayatullah Jakarta, 2009.

Fathonah, Ghina. "Akuisisi Bahasa Kedua", Tesis di Sekolah Pascasarjana UIN Syarif Hidayatullah Jakarta, 2009.

Guasti, Maria Teresa. Language Acquisition; The Growth of Grammar, London: The MIT Press Cambridge, 2002.

Herdinata, Vanda. Dasar-Dasar Psikolinguistik. E-Book. Accesed: http:// vanda.lecture.ub.ac.id/ pada 9 September 2013.

Johnson, Marysia.A Philosophy of Second Language Acquisition, London: Yale University Press, 2004. 
Jumhana, Nana. "Pemerolehan Bahasa Pada Anak", Al-Ittijah Jurnal Keilmuan dan Kependidikan Bahasa Arab, Vol 6, No. 2 (Juli - Desember) 2014.

Krashen, Stephen D. Second Language Acquisition and Second Language Learning, Pergamon Press Inc, 1981.

Markee, Numa, Conversation Analysis Second Language Acquisition Research, Lawrence Erlbaum Associates, Inc, 2000.

Soenjono, Psikolinguistik Pengantar Pemahaman Bahasa Manusia, Jakarta: Yayasan Obor Indonesia, 2008, Edisi Ketiga.

Syahid, Ahmad Habibi. "Kepribadian Ekstrovert-Introvert dan Pemerolehan Bahasa Kedua Perspektif Psikolinguistik pada Santri Pondok Modern", Al-Qalam Jurnal Kajian Keislaman, Vol. 31, No. 2 (Juli-Desember) 2014.
Tarigan, Henry Guntur. Pengajaran Pemerolehan Bahasa, Bandung: Angkasa, 2011 Edisi Revisi.

Tarigan, Henry Guntur. Psikolinguistik, Bandung: Angkasa, 2009, Edisi Revisi.

Tono, Yukio. "The Role of Learner Corpora in SLA Research and Foreign Language Teaching: The Multiple Comparison Approach", a Dissertation at Lancaster University Department of Applied Linguistics and Modern English Language, February, 2002. 